\title{
Social Status of Internal Migrant Women in Durres, Albania
}

\author{
Alkida Ndreka \\ PH.D Candidate \\ alkidandreka@hotmail.com
}

Doi:10.5901/ajis.2014.v3n3p549

\begin{abstract}
Nowadays internal migration is a well-known phenomenon not only for the impact the migrants have on the new community but also for the difficulties internal migrants face to adapt to their new location. The migratory movement does not only mean a physical movement to the city but a change in the way of living resulting in a value system change which is not immediate. Migration is a process where the opportunities and results are different for men and women; that is why we ask the following question: how does the internal migration affect the life and the social status of women? The focus of this article is the perception of migrants on the social status of the migrant women and the influence of their employment on that perception. Albania is developing dynamically as expressed in the social roles of women, gender aspects and in other areas. Gender relations are a focus of strategies which aim to establish gender equality in public life, equal position between men and women, and equal opportunities in all areas of social life. A challenge of Albanian society is women's status in it because of the already evident and sometimes legitimized inferior position they hold. The mentality and labor gender division affect the social roles of migrant women. This article seeks to understand the social status of migrant women and the impact of the internal migration on such status by analyzing different variables such as employment, education, social expectation, social roles etc.
\end{abstract}

Keywords: internal migration, gender, social status, mentality, education.

\section{Introduction}

Migration is defined as "a historical forces that has shaped the world", or as "an integral part of human behavior, referring to the fact that we are dealing with a natural phenomenon, as old as human history itself (E Drejta Migratore, 2009). After years'90 Albanian society was characterized by interior and exterior migratory as a result of the collapse of the communist regime and freedom of the individual to choose the proper profession, place of work and residence (Fuga, 2000). Literally, Albania is a country on the move. Its internal and external migration in the past 15 years, has been massive in rate as well as for its impact. About 20 percent of adults were displaced and one in three households has a migrant abroad (Raport, 2007). This population shift, was voluntary and free, but was not accomplished in an organized manner which have caused negative impacts in their personal life and beyond. Although these population movements were spontaneous and chaotic processes, it viewed as positive, because mainly people have the desire and the human right to a better life, moving towards more developed areas (Shtëpani, 2007). Asside from the triumph of the human right to choose his surroundings, newcomers have had a positive impact on the urban economic development, building materials and service industries. Internal migration from rural to urban areas and especially Tirana-Durres brought urban population growth from $35.5 \%$ in 1991 to $42 \%$ in 2001 . The concentration in urban areas can be very large, if taken into account newcomers settlements on the outskirts of cities, which are considered administratively rural (Strategjia Ndërsektoriale e Perfshirjes Sociale 2007-2013, 2007).

During this exodus, Albanian society was facing a series of problems and phenomena such as urbanization, unemployment, gender equality etc. The dynamics of migration make necessary the increase of investments with demographic character which is also accompanied with increasing of the unemployment and the informal market (INSTAT, 2001). These problems are still present today, despite various interventions aimed at minimizing these negative consequences. This shift is associated with way of thinking, prejudice and "old" lifestyles which affect the position and role of woman in family and society. Faced with such a situation, recognition of women's social status and the impact of migration on changing this status is an important issue.

The definitions for social status are varied but this study will be realize in the framework of the status as a social role. Study of social status is sociologically important because it refers to a straight set rights, obligations, behaviors and tasks that people depending on a certain position, or encouraged or tend to realize. These expectations belongs to social roles. Social status of women according to the authors is identified with employment therefore one of the indicators 
analyzed is employment, although the focus is in internal migration and the impact that it has on the social status of migrant women.

This study includes two key spheres: gender and migration, which are currently relevant and very valuable topics for Albanian society. The focus of this study is to combine and analyze two important features of the process of transformation of Albania-flow of internal migration and changes in the status of women in society. In an effort to analyze the existing situation, in this study will try to answer questions such as:What are the reasons that encourage internal migration? Which are the factors that affects woman's social status? What is the crucial role of the internal migration in the status of migrant women, how it affects: in the improvement or deterioration?

\section{The Definition of Social Status and Influencing Factors}

Different authors have determined different definitions about social status. According to Weber status it is related to differences between social groups by social titles and Honor granted by others. (Giddens, 2004). Weber emphasizes the differences that exist between social class which is given in an objective way and status which depends on subjective evalution made to social differences. In its analysis, the class derives from economic factors while the status is determined by the different ways of life that own members or groups of society.

In further analysis of literature A. Hollinshead defines social status as a multidimensional concept, setting several factors which determine social status. The author emphasizes that the determination of social status continues to be problematic in sociology and sociologists have debated for a long period how can be determined the position of the individual in a society. So according to this view, the status is defined as the position that an individual has in a specific society. He conducted a series of studies to identify the social status in the western communities. Hollinshead create a new index which can be used to determine the status of individuals. The new index takes in consideration the fact that social status is a multidimensional concept (Hollinshead, 1975). In this logic, he notes that there are three main assumptions: the first is related to the fact that in society there are unequal status structure, the second one is that the main factors determining social status are employment, personal commitment, education, as well as sex and marriage status. Third, these factors can combine with each other, so the researcher can evaluate individual status of an individual in society.

Knoke David and Marcus Felson have done an analysis of the social status of married women. According to these theorists, in this case, it becomes possible the influence from both partners in status model, giving up the model which describes the woman with no or less influential in the status of their spouses. If both spouses influence achieving of each status this would mean a model for sharing of the status which includes some levels of reciprocity (Felson \&Knoke, 1974).

\section{Methodology}

The main method used for data collection in this study is survey. The instrument used is questionnaire. Also it has been used the existing literature regarding the topic of study, whose browsing informs, guides and encourages further research scholar or certain aspects of a social phenomenon.

The survey is taken place in the city of Durres, in the neighborhood.15 (Spitallë). This neighborhood is known for the large number of internal migrants, so the study was realized over there. For the realization of this study were surveyed 400 individuals therefore total 400 questionnaires were completed. The number of respondents was 132 males and 268 female. The questionnaires were filled out in the field and the sample was selected in a completely random way. Also respondents are pertinent to different civil status, different education, employed or not (and in different sectors) in order to be more diverse such the responses and to enrich as much as possible the real situation of women in this area.

\section{Results and Discussions}

\subsection{Evidence of the phenomenon of internal migration}

This study concludes that internal migration is such a phenomenon which in these recent years has had lower rates. The survey data refer to a mass migration of at least 10 years ago, while during the ongoing migration shows up as a sporadic phenomenon. The major part of the residents moved nearer to Spitalla's area are transferred from the district of Dibra, showing that northern areas tend to move towards regions where there is more investment and employment opportunities. This district represents the area which has generated the more such an internal migration in Spitalla's 
neighborhood.

Economic disparities between districts give a further boost to the internal migration; the majority of respondents have determined that the reason which has prompted their displacement is opportunity to employ them in the country migrated. With the hope of finding a job, individuals from different areas of Albania are displaced in Spitalla's one hoping so in a labor market more accessible by them. The migrants represent just willingness and individual freedom and a process as well which in its essence intent the change, hence the improvement the socio-economic situation.

\subsection{Social status of migrant women}

Education is considered as the main influential factor in a woman's social status. This prevailing perception aside from the fact related to the education which is one of the values that has traditionally been evaluated by the Albanian society, it is also explained by the assessment of formal education as derivative of other elements. An educated woman is supposed to own other qualities that derive from education: such as being more capable in the family, it becomes easier to get a job for herself, she has better educational and communication skills as well. Education besides the fact reflects all the knowledge an individual has accumulated, constitutes an element whereby women get respect in the social system. Formal education is a factor whereby the woman increases the impact on family and decision and gains social estimate.

Internal migration seems to have had positive effects on women's social position. This kind of social status improvement is mainly related to the employment and lifestyle, thus displacement within the country has resulted in the reduction of hard works such as working the land, care of livestock, etc. This has facilitated the lives of women and improvement of their way of living.

Integration of women of Spitalla's neighborhood in the community is classified as low-scale integration. This situation results as a combination of three main factors. Change of political systems in Albania, whereby it was abandoned any form of a common activity, making democracy look, not as citizens undertaking with common goals, but as a closed society, where everyone tries to solve their own problems, where an individual closes himself into the shell of his proper private life. Mentality direct women towards social roles which translates it to home care and upbringing of children, and of course, this social role requires time and energy by limiting so the integration of women in the community. Prejudices constitute such a third reason which it adversely affects the community integration of a woman. Prejudices between newcomers and natives lead to a lack of cooperation and understanding in the community. The combination of these reasons consequently influence of the low level of women's integration into the community of this area.

Internal migration is realized under the influence of such factors of socio-economic nature. Relocation involves adapting to lifestyles and life organization in town, the new community. Faced with this situation, internal migration is associated with a number of problems and uncertainties which affect the welfare of the displaced family. One of them is the employment of migrants, which directly affects the existence and functioning of the family. Employment is a keystone in the psycho-cultural constitution of the people and in their overall activity cycle. Despite the perception that emphasizes the employment such a very important element in the life of a migrant woman, it is conditioned by objective and subjective factors. Employment is an expression of the individual will but the existence of a number of other cultural factors condition the employment of migrant women.

Unemployment in Spitalla is primarily a female phenomenon, the lack of education and vocational training influence and hinders the participation of migrant women in the labor market. Poverty, mentality, the lack of education schools reduce the possibility of education of girls and women, this lack of investment in education is transmitted further in their lives becoming much more difficult the employment, self-realization and their emancipation.

Employment fulfills so many functions which have a positive impact on the life of a woman, whereas the lack of employment is one of the main factors that adversely affects her status, her personality in the family and society. Employment is defined as the activity which improves household economic conditions, other aspects such as the creation of social connections and recreation, social assessment, participation in training and conferences and the empowerment of social role still remain secondary issues in Albanian society. The employed woman becomes potentially as a contributor to the family, but what is disturbing is the fact that this contribution of woman in the family does not affect the strengthening of her social role for the improvement of social status. Despite identifying as a crucial element in a woman's life, the employment does not constitute a basic factor in strengthening of the social status of a woman. The way of perceiving by the respondents is conditioned by the education and social mindsets which continue to emphasize gender roles. In this way the employment is defined as a means to supplement the family income rather than empowering the social role of women. Shaping of individuals with such ideas that emphasize the role of men in families and undermine the position, the role of women in family obviously affects the importance and the impact that the employment has in the woman's life. Albanian mentality burdens on women who belittles and oppresses, minimizing so the possibility of self- 
realization. In this social atmosphere, the perception of women's employment is associated with such dose of pessimism because their income is often considered secondary one without a major impact on the family. The improving of social status depends on mainly on self-awareness of women onto the social role that have in their families and society, further it is influenced by the awareness of all other social actors.

It is the youngest age group that one who evaluate the social empowerment of a woman, besides the fact they are more sensitive to social status, they however constitute the most emancipated and framed with the basic principles of a society that promotes gender equality and social assessment of women. It is understandable that most educated respondents have determined the social empowerment of women; the education influences their perceptions of social status and social assessment of a woman. Educated individuals are generally the most emancipated society which "fights" patriarchal elements of the proper society.

Facilities in employment make up such alternative through which they could improve the social status of a woman. Leaving aside any idealism, individuals focus on the more practical element and the direct impact on family life such as employment.

Albanian society is characterized by high doses of nepotism; it prevents the employment of individuals not being given to them the opportunity of a fresh equal initiation. This situation becomes more difficult for internal migrants who have not consolidated their social connections yet, which often function as "employment agencies" whereby there is the possibility to be informed about new workplaces. This selected option is directly related to employment, but after that, it is "camouflaged" the assessment of income statement because despite all this, the males continues to be superior in family life, economic and social one. The only change result in employment outside the home brings economic income, in analogy with the unpaid works that are still determined worthless and feminine domain. The income does not strongly affect the social status of a woman, it is just the masculine mentality that identifies the wife as a second sex cause of it subjugations her to the man, all this explains the unfavorable position in which migrant women are currently situated.

\section{References}

Felson,M., \& Knoke.(1974) Journal of marriage and family. University of Ilinois.

Fuga, A. (2004). Shoqëria Periferike. Tiranë.

Hollingshead, A. (1957). Four factor index of social position. Yale University New Haven, Connecticut.

Giddens, A. (2004). Sociologjia. Tiranë.

Shtëpani, V.(2007). Sociologjia Urbane.Tiranë.

Manual Trajnues (2009) E drejta migratore.

INSTAT (2001) Migracioni në Shqipëri, Regjistrimi i popullsisë dhe i banesave.

Strategjia Ndërsektoriale e Perfshirjes Sociale 2007-2013 (2007).

Raport (2007) Shqiperia: Zhvillimi Urban, Migrimi dhe Ulja e Varferisë. Dokument i Bankës Botërore. 